\title{
Perubahan Sosial Budaya Masyarakat Akibat dari Kemajuan Ilmu Pengetahuan dan Teknologi di Dusun Batukol Kabupaten Barito Selatan
}

\author{
KARUNIA SANTI \\ Pendidikan Ilmu Pengetahuan Sosial, Universitas Lambung Mangkurat \\ e-mail:1810128220034@mhs.ulm.ac.id
}

\begin{abstract}
ABSTRAK
Perubahan sosial dan budaya merupakan gejala dari perubahan kondisi sosial dan budaya dalam suatu masyarakat. Perubahan sosial dan budaya merupakan gejala yang selalu terjadi pada setiap masyarakat. Penulisan artikel ini bertujuan untuk: 1) mendeskripsikan kondisi lingkungan Dusun Batukol, Kabupaten Barito Selatan. 2) mendeskripsikan aktivitas sosial masyarakat akibat kemajuan ilmu pengetahuan dan teknologi. 3) mendeskripsikan penyebab terjadinya perubahan sosial budaya masyarakat dalam konteks kemajuan ilmu pengetahuan dan teknologi. 4) mendeskripsikan pengaruh perubahan sosial budaya terhadap masyarakat Dusun Batukol, Kabupaten Barito Selatan. Pengumpulan data dilakukan melalui pengalaman pribadi penulis, telaah literatur, buku dan majalah tentang perubahan sosial budaya akibat kemajuan ilmu pengetahuan dan teknologi. Hasil dari penelitian ini adalah: 1) Tradisi masyarakat yang mengandung nilai-nilai dan telah turun temurun dan berubah dari generasi ke generasi sejak lama. Berupa gagasan dan kegiatan, serta hubungan antara manusia dengan Tuhan, manusia dengan manusia dan hubungannya dengan lingkungan. 2) Masyarakat memandang pentingnya hubungan sosial yang baik untuk menjaga keharmonisan. 3) Terdapat faktor-faktor yang menyebabkan dan mempengaruhi terjadinya perubahan sosial budaya masyarakat desa yang menyebabkan kondisi sosial budaya yang berbeda pada tahun sebelumnya.
\end{abstract}

Kata Kunci: Perubahan sosial, kebudayaan, masyarakat, Indonesia

\section{PENDAHULUAN}

Perubahan sosial dan budaya merupakan suatu gejala yang selalu terjadi dalam hidup manusia. Perubahan yang terjadi erat kaitannya dengan kehidupan masyarakat serta terjadinya suatu budaya yang muncul beriringan dengan terjadinya suatu perubahan yang terjadi dalam masyarakat. Seiring berjalannya waktu setiap masyarakat pasti akan selalu mengalami perubahan, baik berubah secara cepat ataupun secara lambat. Kehidupan manusia tidak hanya berhenti di satu titik, tapi akan terus berputar sesuai tuntutan zaman yang semakin modern. Perubahan membutuhkan proses, proses dalam pemaknaan sosial pada hakikatnya adalah jalan kehidupan suatu masyarakat, yang menunjukkan dirinya dalam dinamikanya baik setelah evolusi biologis dalam siklus kehidupan, maupunserta perubahan perilaku dalam situasi yang berhubungan dengan sosial masyarakat (Ranjabar, 2015:12). Kemajuan ilmu pengetahuan dan teknologi berdampak besar bagi perkembangan kehidupan manusia, karena kemajuan teknologi yang terjadi dapat memberikan dampak positif maupun negatif bagi kehidupan masyarakat. Kita ketahui bahwa kemajuan akibat perkembangan ilmu pengetahuan dan teknologi dapat membawa perubahan yang sangat besar pada lingkungan masyarakat. Seiring dengan perkembangan ilmu pengetahuan dan teknologi, manusia harus mengikuti arah perubahan sesuai dengan perkembangan zaman. 
Terjadinya perubahan sosial budaya dipengaruhi oleh beberapa faktor, antara lain pertumbuhan penduduk, penemuan barang/teknologi baru, konflik/masalah dan pengaruh dari budaya lain yang menimbulkan budaya campuran atau akulturasi budaya. Ada beberapa hal yang menjadi fokus perhatian penulis disini yaitu antara lain: 1) Bagaimana status lingkungan hidup warga Dusun Batukol Kabupaten Barito Selatan? 2) Bagaimana kegiatan sosial masyarakat yang berbasis kemajuan ilmu pengetahuan dan teknologi? 3) Faktor apa saja yang menyebabkan terjadinya perubahan sosial budaya pada masyarakat ? 4) Apa pengaruh perubahan sosial budaya terhadap masyarakat?. Penulisan artikel ini bertujuan untuk mengetahui: 1) Tradisi masyarakat yang mengandung nilai-nilai dan telah turun temurun dan berubah dari generasi ke generasi sejak lama. Berupa gagasan dan kegiatan, serta hubungan antara manusia dengan Tuhan, manusia dengan manusia dan hubungannya dengan lingkungan. 2) Masyarakat memandang pentingnya hubungan sosial yang baik untuk menjaga keharmonisan. 3) Terdapat faktor-faktor yang menyebabkan dan mempengaruhi terjadinya perubahan sosial budaya masyarakat desa yang menyebabkan kondisi sosial budaya yang berbeda pada tahun sebelumnya.

\section{METODE}

Metode penulisan artikel ini adalah metode kualitatif dengan pendekatan deskriptif analisis. Penelitian yang diperoleh disajikan dalam bentuk uraian kalimat penelitian menganalisa Perubahan Sosial Budaya Masyarakat Akibat dari Kemajuan Ilmu Pengetahuan dan Teknologi di Dusun Batukol Kabupaten Barito Selatan.

Sumber data dalam penulisan ini meliputi lisan dan tulisan yaitu berupa pengamatan, tindakan, dan data tambahan yang relevan. Penulis kemudian mengumpulkan data primer dan sekunder. Sumber data primer penulis dapatkan dari hasil pengamatan dan pengalaman langsung penulis di dusun tersebut dengan penduduk sedangkan data sekunder berupa sumber tertulis, foto, arsip dan dokumen.

\section{HASIL DAN PEMBAHASAN}

Indonesia merupakan negara dengan kondisi masyarakat yang majemuk dengan kondisi sosial serta budaya yang berbeda disetiap wilayahnya, kemajemukan inilah yang menjadikan Indonesia sebagai negara yang kaya akan budaya, agama, suku, ras dan adat istiadat masyarakat. Masyarakat indonesia sekarang ini sedang mengadakan pembangunan di era reformasi dengan sistem desentralisasi (otonomi daerah) mengakibatkan terjadinya perubahan sosial yang ditimbulkan persentuhan luar, (Ranjabar, 2015:176).

Perubahan sosial tadi akan menjadi sebuah kekuatan positif bagi rakyat dalam upaya merubah kondisi masyarakat jika perubahan tadi bisa diarahkan. Namun, bisa jadi malah sebaliknya, perubahan tadi juga bisa berdampak negatif jika rakyat tak bisa mengendalikannya dan akan menjadi bumerang bagi masyarakat sendiri. Untuk mengendalikan dan mengarahkan perubahan tadi, perlu sosialisasi dan pemahaman akan perubahan sosial dengan asa untuk sebuah kemajuan.

Barito Selatan merupakan salah satu Kabupaten di Kalimantan Tengah yang ada di Indonesia, dengan berbagai potensi yang berada di dalamnya diantaranya potensi industri serta pariwisata. Wisata yang sangat terkenal di Buntok, Kabupaten Barito Selatan sendiri yaitu seperti Danau Sanggu, Danau Malawen, Rumah Betang Nansarunai dan Danau Sadar. Kabupaten Barito Selatan terletak di Sebelah Utara 
dengan Kabupaten Barito Utara. Sebelah Timur dengan Kabupaten Barito Timur. Sebelah Selatan dengan Kabupaten Hulu Sungai Utara (Provinsi Kalimantan Selatan). Kabupaten Barito Selatan terdiri dari 6 kecamatan, 7 kelurahan, dan 86 desa. Dusun Batukol merupakan salah satu Dusun yang terdapat di Desa Maruga, Kecamatan Dusun Utara Kabupaten Barito Selatan. Dusun inilah yang akan penulis coba kaji mengenai fenomena perubahan sosial masyarakat dengan kondisi sosial yang berubah, juga tentang munculnya perubahan budaya. Dalam penulisan artikel ini berfokus pada kondisi lingkungan serta aktivitas masyarakatnya yang dipengaruhi adanya kemajuan dalam bidang ilmu pengetahuan dan teknologi.

Sudah tak asing bagi kita bahwa setiap perubahan di karenakan adanya faktorfaktor yang menyebabkannya. Pada artikel ini penulis akan menyebutkan faktor terjadinya perubahan masyarakat, baik faktor pendukung maupun faktor penghambat dan menganalisis dampaknya berdasarkan adanya perubahan sosial budaya masyarakat. Adanya hubungan antar warga di Dusun Batukol ditambah pengaruhnya dari luar, berdasarkan antar wilayahnya juga pengaruhnya secara global. Seiring berjalannya waktu, unsur-unsur dari luar akan diadopsi oleh warga masyarakat dan tentunya kehidupan sosial masyarakat yang lalu akan berubah.

\section{a. Kondisi Lingkungan}

Dusun Batukol merupakan salah satu dusun di kecamatan Dusun Utara yang berada di kabupaten Barito Selatan yang letaknya masuk ke pedalaman yang jauh dari adanya jalan raya. Bersebelahan langsung dengan desa Maruga. Jumlah penduduknya sedikit bahkan tidak mencapai 200 kepala keluarga. Masyarakat Dusun Batukol penduduknya beragama Kristen Protestan, Katolik, Islam dan beberapanya masih menganut kepercayaan Kaharingan. Masyarakat bermata pencaharian sebagai petani getah karet, guru, buruh sawit dan pekerjaan lainnya yang didapatkan oleh masyaraakat di perantauan.

Selain Desa Maruga, dusun Batukol juga dekat dengan Desa Panarukan dan Desa Reong, kondisi lingkungan dusun ini tidak padat, masyarakat di dusun ini sangatlah ramah, hubungan sosial masyarakatnya juga baik. Masyarakat Dusun Batukol merupakan masyarakat yang masih mempunyai adat kepercayaan, mereka masih sangat menghormati tradisi yang diwariskan leluhur 1) Seperti memberikan sesajen ke hutan ketika musim menanam padi atau suatu acara tertentu yang membuat masyarakat ingin melaksanakan tradisi itu. 2) Bergotong royong membantu sanak saudara atau keluarga ketika menanam padi atau panen padi, juga sistem kekeluargaan dan lain sebagainya. Ciri khas masyarakatnya adalah selalu membantu antar warga ketika ada suatu acara tertentu, baik itu acara adat maupun acara keagamaan.

Menjadi sebuah ciri khas di dusun ini yaitu dimana para laki-lakinya cenderung bekerja merantau ke luar kota dan kebanyakan dari mereka mendirikan usaha-usaha kecil atau besar dan ada yang bekerja disekitar rumah mereka, baik sebagai petani karet getah dan lain sebagainya. Hal tersebut merupakan ciri khas masyarakat di Dusun Batukol, tentu hal tersebut juga dipengaruhi karena kondisi lingkungan yang mayoritas sebagai petani buruh karet dan selain itu sedikitnya lapangan pekerjaan di sekitar dusun mengingat dusun ini terletak di daerah yang cukup terpencil.

Kehidupan masyarakat tidak lepas atau erat kaitannya dengan dimana lingkungan mereka tinggal. Hal itu akan turut mempengaruhi berbagai aspek 
kehidupan masyarakat, tidak terkecuali bagi aspek sosial dan ekonomi masyarakat.

\section{b. Aktifitas Sosial Kemasyarakatan}

Perubahan sosial budaya tidak membuat banyak perubahan dalam hal kondisi masyarakat dalam bidang toleransi. Namun, adanya ilmu pengetahuan dan teknologi tentu saja telah merubah kondisi masyarakat, sedikit demi sedikit. Dalam hubungan berinteraksi dan aktifitas sosial cenderung memilih menggunakan teknologi namun masih dalam tahap wajar karena masih sulitnya jangkauan listrik dan internet ke dusun ini, perlahan masyarakat Dusun Batukol (mayoritas remaja dan dewasa) seiring dengan mengenal teknologi terutama di bidang internet mulai aktif dalam penggunaan media sosial seperti facebook dan Whatsapp. Meskipun masih ada yang tidak mengerti akan teknologi tapi tidak sebanyak dengan yang sebelumnya. Fenomena semacam ini terjadi pada masyarakat tradisional seperti masyarakat Dusun Batukol kecamatan Dusun Utara Kab. Barito Selatan, yang sudah mulai menghilangkan warisan budaya leluhur seperti adat balian memanggil roh-roh halus untuk menyembuhkan penyakit yang sudah tidak ada lagi karena masyarakat mulai tidak mempercayainya karena sudah memeluk suatu agama.

Hanya toleransi dan kebersamaan gotong royong saling membantu yang masih berjalan sampai saat ini. Tentu ada sebuah kontra terhadap pengaruh dari luar, namun sebaiknya masyarakat tidak mengasingkan diri mereka dari pengaruh tersebut. Terutama pengaruh dari kemajuan ilmu pengetahuan dan teknologi.

Nilai gotong royong yang sangat kental dengan masyarakat Indonesia membuat bangsa yang majemuk ini semakin berwarna tanpa membedakan warna kulit, agama, ras, suku, dan lain-lain. Masyarakat Indonesia selalu mencontohkan bahwa dengan kerjasama ketika mengerjakan kegiatan kemasyarakatan dapat membangun rasa kebersamaan dalam masyarakat saat ini, apalagi dengan berkembangnya kehidupan masyarakat baru atau Society 5.0 untuk mengurangi rasa stagnasi dan menjadikan kehidupan masyarakat lebih aktif dan menyenangkan. (Abbas, 2020 ).

Terjadinya perubahan dapat mengubah kondisi masyarakat serta kondisi ekonomi dan hubungan interaksi sosial, selain itu juga dapat mempengaruhi hubungan manusia dengan Tuhan.

Wahyu (Dalam Mutiani,dkk. 2019) konsep kearifan lokal, yang dalam terminologi budaya dapat diinterpretasikan sebagai pengetahuan yang berasal dari budaya masyarakat yang unik, mempunyai hubungan dengan alam dalam sejarah panjang, beradaptasi dengan sistem ekologi setempat, bersifat dinamis dan selalu terbuka dengan tambahan pengetahuan baru. Dengan kata lain, merupakan pengetahuan lokal yang unik, berasal dari budaya masyarakat setempat serta menjadi dasar pengambilan keputusan pada tingkat lokal dalam berbagai bidang kehidupan manusia.

Sampai saat ini masyarakat dusun Batukol pada umumnya masih mempertahankan profesi petani, masyarakat masih memelihara sawah/ladang/rawa di pertanian untuk bercocok tanam atau sebagai petani, meskipun selain itu banyak juga yang berprofesi sebagai pedagang atau yang 
lahannya digunakan. Tentu saja hal ini tidak lepas dari perubahan sosial dan budaya yang terjadi di masyarakat.

\section{c. Penyebab Perubahan Sosial dan Kebudayaan}

Faktor penyebab perubahan sosial budaya sudah tidak layak lagi, bisa jadi faktor baru yang lebih cocok bagi masyarakat untuk menggantikan yang lama. Menurut Soerjono Soekanto dalam bukunya Sosiologi suatu pengantar, faktor dari dalam perubahan sosial budaya dipengaruhi oleh 1) bertambah atau berkurangnya penduduk 2) penemuan-penemuan baru, 3) konflik dalam masyarakat, dapat juga dari faktor luar dikarenakan adanya : 1) sebab-sebab yang berasal dari lingkungan alam fisik yang ada di sekitar manusia, 2) peperangan, 3) pengaruh kebudayaan lain, (Soekanto \& Solistyowati, 2013:275282).

Faktor penyebab perubahan dapat diketahui dari dalam berupa sikap menerima dan kebutuhan masyarakat, serta faktor dari luar karena adanya pengaruh kebudayaan luar, sikap menghargai hasil karya (Gunawan dkk, ), berupa teknologi. Kebudayaan yang terdapat lantaran perubahan sosial budaya pada dampak kemajuan teknologi sudah dimanfaatkan rakyat misal dengan adanya rakyat yang membuka foto copy dan jasa penjualan online. Namun tak bisa dipungkiri pula terdapat masyarakat yang memanfaatkan internet untuk halhal yang kurang bermanfaat.

Klasifikasi terhadap media berdasarkan subtansinya, antara lain (1) saluran penyampai informasi, (2) komponen di sekitar siswa yang mampu merangsang mereka belajar, (3) alat fisik yang dapat menyajikan pesan pembelajaran, dan (4) bentuk komunikasi seperti cetak, audio, visual, maupun audio-visual yang digunakan siswa untuk belajar. (Susanto dkk, 2021)

Kebudayaan adalah seluruh cara kehidupan dari masyarakat dan tidak hanya mengenai sebagian tata cara hidup saja yan dianggap lebih tinggi dan lebih diinginkan. Jadi, kebudayaan dapat merujuk pada berbagai aspek kehidupan, yang meliputi cara-cara berperilaku, kepercayaan dan sikap masyarakat dan kegiatan yang khas dari suatu masyarakat, (Aziz dkk, 2014:134). Perubahan sosial dan budaya di dusun Batukol juga disebabkan oleh faktor lingkungan akibat adanya kemajuan ilmu pengetahuan dan teknologi dapat mendorong perubahan sosial dan masyarakat, seperti masuknya internet di dusun Batukol, secara tidak langsung masyarakat mengalami perubahan, baik dibidang sosial, ekonomi maupun budaya masyarakat. semakin adanya perkembangan ilmu pengetahuan dan teknologi, masyarakat dusun Batukol mengalami perubahan, yang dulunya buta teknologi, dan kesulitan mengakses dunia luar sekarang menjadi mengerti tentang teknologi dan lebih mudah mengetahui informasi lebih cepat tidak hanya melalui tv maupun kerabat saja.

Proses globalisasi meniadakan batas-batas geografis (borderless). Sebagai bangga multikultural, Indonesia mempunyai Pancasila sebagai way of life; pengikat kebangsaan dalam character and national building. Sekalipun demikian, kondisi obyektif menunjukkan, bangsa Indonesia harus lebih giat dan lebih serius membenahi SDM, terutama generasi mudanya, berbasis nilai-nilai luhur bangsa. Nilai-nilai budaya yang diintemalisasikan menjadi benteng jati diri terhadap budaya asing. Dalam transformasi nilai-nilai budaya, pemerintah 
Republik lndonesia mengembangkan sistem pendidikan nasional berbasis keberagaman, satu diantaranya melalui pembelajaran ilmu pengetahuan sosial (IPS) (Abbas, 2020).

\section{d. Dampak Terjadinya Perubahan Sosial Budaya}

Gaya hidup seseorang ditentukan tidak hanya oleh individu tersebut tetapi juga oleh lingkungan dimana ia tinggal, pengaruh globalisasi mengubah gaya hidup anak muda di dusun Batukol melalui pengamatan dan penjelasan dari orang-orang yang cukup baik dengan kemajuannya. Ilmu pengetahuan dan teknologi memang cenderung mempermudah aktivitas. Dengan adanya teknologi dapat membawa dampak bagi penggunanya, kemajuan teknologi dalam segi negatifnya yaitu teknologi disalahgunakan untuk menyebar-nyebar berita hoax, kebencian dan konten-konten negatif yang bisa diakses, dalam segi positifnya yaitu mudah mendapatkan informasi terkini.

Implikasi dari perubahan suatu sistem budaya yang di anut masyarakat mengakibatkan terjadinya pengaruh yang signifikan terhadap nilai-nilai budaya, jika kita melihat perubahan sosial sebagai dampak dari berkembangnya teknologi adalah dengan mudahnya mengakses internet yang bagi masyarakat yang tidak agamis dapat digunakan untuk hal-hal negatif, (Syamsidar, 2015:104105). Kita dapat melihat bahwa banyak terjadi kecurangan, ketidakjujuran, dan perbuatan negatif lainnya yang bertentangan dengan norma hukum maupun agama sebagai dampak perubahan sosial.

Keberadaan teknologi seiring perkembangan jaman, seakan menjadi suatu kebutuhan bagi manusia untuk kelangsungan hidupnya. Adanya teknologi membantu memecahkan masalah yang ada namun juga tidak luput menimbulkan masalah lain. Kemajuan iptek dalam kehidupan masyarakat dusun Batukol mempengaruhi aktifitas sosial diantaranya: 1) mata pencaharian warga 2) keefektifan dalam berkomunikasi, 3) perubahan lingkungan alam. Pengaruh perubahan sosial budaya akibat kemajuan ilmu pengetahuan dan teknologi adalah terjadinya transformasi pemikiran dalam pendidikan, seiring dengan perubahanperubahn sosial yang terjadi dalam masyarakat, pendidikan juga mengalami perubahan, (Yasmadi, 2004:125).

Hastuti (dalam Jumriani, 2018: 110) daya manusia dan pendidikan berpengaruh terhadap perkembangan usaha kerajinan, karena sumber daya manusia yang terampil dan profesional akan. produksi yang berkualitas sehingga banyak diminati dan berpengaruh terhadap usaha kerajinan yang dijalankan. Maka terjadinya perubahan dalam suatu masyarakat dengan memperhatikan nilai dan norma budaya yang baru muncul sangat diperlukan agar tercipta kondisi sosial budaya masyarakat yang lebih baik.

\section{e. Simpulan}

Berikut simpulan yang dapat diambil dari penulisan artikel yang telah diuraikan di atas: Perubahan masyarakat tentu sangat dipengaruhi oleh kemajuan 
ilmu pengetahuan dan teknologi. Terkait dengan perubahan negatif dalam masyarakat yang akan mempengaruhi budaya yang baik, tetapi penting untuk diketahui bahwa perubahan sosial budaya karena kemajuan ilmu pengetahuan dan teknologi dapat memudahkan masyarakat untuk memenuhi kebutuhannya dan memiliki visi untuk menyediakan yang berkomitmen untuk tujuan kesejahteraan masyarakat.

Berdasarkan simpulan tersebut, maka dapat direkomendasikan hal-hal sebagai berikut: 1) Sosialisasi sikap diperlukan untuk menerima perubahan sosial budaya yang terjadi di masyarakat, 2) Perlunya kerjasama antara berbagai pihak, baik peran orang tua, pendidik maupun orang-orang yang lebih mengerti tentang pengkondisian perubahan yang terjadi, serta dilakukan sesuai standar dan nilai yang berlaku.

Seperti Menurut Suwarma Al Muchtar (dalam Abbas ,2018) Perubahan sosial budaya sangat cepat dan menyentuh perubahan sistem nilai, sehingga mempengaruhi terhadap intensitas masalah sosial budaya. Kompleksitas masalah sosial budaya semakin menguat memicu terjadinya situasi turbulensill. Situasi seperti itu merupakan latar sosial budaya pendidikan IPS, merupakan tantangan bagi upaya peningkatan mutu pendidikan IPS baik dalam tatanan nasional hingga global. Demikian pula dalam pengembangan pemikiran paradigmatif bagi pengembangan sistem pendidikan guru IPS di perguruan tinggi.

Pembelajaran IPS menekankan pada aspek "pendidikan" dari pada transfer konsep karena dalam pembelajaran IPS peserta didik diharapkan memiliki pemahamanan sejumlah konsep dan mengembangkan serta melatih sikap, nilai, moral dan keterampilannya berdasarkan konsep yang telah dimilikinya (Abbas, 2020).

\section{REFERENSI}

Abbas, E. W. (2018). Penguatan Pendidikan IPS Di Tengah Isu-Isu Global.

Abbas, E. W. (2020). Metode Guru Sekumpul Sebagai Inovasi Pembelajaran IPS Berbasis Budaya Lokal.

\section{Jumriani, J. (2018). KEGIATAN PRODUKSI DAN DISTRIBUSI DI KAMPUNG} SASIRANGAN SEBAGAI SUMBER BELAJAR IPS. Jurnal Socius, 7(1).

Maryanto, M., \& Azizah, L. N. (2019). Perubahan Sosial Budaya Masyarakat Desa Ngebalrejo Akibat Kemajuan Ilmu Pengetahuan dan Teknologi. Indonesian Journal of Social Science Education (IJSSE), 1(2), 181-190.

Mutiani, M., Subiyakto, B., Jumriani, J., Aslamiah, A., \& Afrina, A. (2019). Laporan Penelitian: Relevansi Modal Sosial Dalam Pembelajaran IPS (Studi Kasus Dalam Sistem Zonasi Di Smp Negeri Kota Banjarmasin). 
Putro, H. P. N., \& Jumriani, J. (2020). KEHIDUPAN SOSIAL DAN EKONOMI MASYARAKAT BANTARAN SUNGAI A SEBAGAI SUMBER BELAJAR IPS.

Syaharuddin, S., Handy, M. R. N., Jumriani, J., Faisal, M., \& Maulana, I. (2020). The Values of Gotong Royong on BPK (Fire Brigade) Social Activities in Banjarmasin. The Kalimantan Social Studies Journal, 2(1), 62-68.

Susanto, H., Irmawati, I., Akmal, H., \& Abbas, E. W. (2021). Media Film Dokumenter dan Pengaruhnya Terhadap Keterampilan Berpikir Kritis Siswa. HISTORIA: Jurnal Program Studi Pendidikan Sejarah, 9(1), 65-78.

Subiyakto, B., \& Abbas, E. W. (2020). Strategi Pembelajaran IPS: Konsep dan Aplikasi. 